\title{
PELATIHAN PEMANFAATAN CYBER COUNSELING BERBASIS MOBILE UNTUK MEMAKSIMALKAN KOMPETENSI SISWA MAGANG DI SMKN BALI MANDARA
}

\author{
Agus Aan Jiwa Permana ${ }^{1}$, Made Putrama ${ }^{2}$, Komang Setemen ${ }^{3}$ \\ ${ }^{123}$ Jurusan Teknik Informatika, Universitas Pendidikan Ganesha \\ e-mail: agus.aan@undiksha.ac.id, made.putrama@undiksha.ac.id, \\ k.setemen@undiksha.ac.id.
}

\begin{abstract}
Abstrak
Salah satu sekolah vokasi di Bali yang giat dalam mencetak lulusan dengan target $70 \%$ lulusan bekerja di Industri adalah SMKN Bali Mandara. Mellaui hasil observasi dan wawancara di sekolah dengan pimpinan dan guru di SMKN Bali Mandara ditemukan informasi bahwa minimal $70 \%$ siswanya ditargetkan bekerja. Permasalahan yang dihadapi oleh mitra yang merupakan sekolah vokasi ini adalah bagaimana cara membentuk karakter siswa selain memiliki kecerdasan interpersonal juga memiliki kompetensi yang unggul. Melalui pengabdian tahun 2020, pengabdi sudah melaksanakan pelatihan kepada tim guru dan staff di SMKN Bali Mandara untuk melakukan seleksi siswa baru menggunakan tes online bernama Simaju (Sistem Peminatan Jurusan) yang kemudian dikenal dengan SimajuGanesha. Melalui kerjasama dengan pihak sekolah, pelatihan bertujuan memperkenalkan aplikasi mobile. Adapun peserta yang megikuti adalah guru dan siswa kelas XII yang akan magang. Hasilnya pelatihan berupa (1) pedoman user manual software, (2) hasil tes software lokasi yang sesuai dengan minat siswa.
\end{abstract}

Kata kunci: Tes Kompetensi Magang, Cyber Counseling, aplikasi Mobile

\begin{abstract}
One of the vocational schools that is intense in producing graduates with a target of $70 \%$ of graduates working in industry is SMKN Bali Mandara. Through direct communication with Mr. I Wayan Agustiana, S.Pd., M.Pd as the Principal and Vice-Chancellor and Teacher at SMKN Bali Mandara said the same thing, namely at least $70 \%$ of the students are targeted to work. The problem faced by partners who are vocational schools is how to shape the character of students in addition to having interpersonal intelligence but also having superior competence. Through the 2020 service, the service has carried out training for a team of teachers and staff at SMKN Bali Mandara to select new students using an online test called Simaju Ganesha. Through collaboration with the school, the training aims to introduce mobile applications. The participants who follow are teachers and class XII students who will be doing internships. The results of the training are (1) user manual software guidelines, (2) location software test results that are in accordance with student interests.
\end{abstract}


Keywords : Internship Competency Test, Cyber Counseling, Mobile Application

\section{PENDAHULUAN}

SMKN Bali Mandara merupakan seolah menengah kejuruan yang memiliki potensi besar menghasilkan lulusan yang mampu terserap di dunia kerja, unggul, dan berkarakter. Dalam proses peminatan jurusan di SMK Bali Mandara sudah dibantu dengan menggunakan Sistem SimajuGanesha (Gambar 2), wawancara (Gambar 3), home visit (Gambar 4), dan basecamp (Gambar 5). Berdasarkan pengalaman penulis saat melakukan sosialisasi ke sekolah ini, hal luar biasa yang dirasakan saat masuk sekolah adalah sapaan ramah dari siswa, guru, security yang selalu ramah kepada pengunjung dengan senyum di wajah mereka. Penulis yakin siapapun yang datang kesana pasti akan merasakan suasana damai di hati karena suasana ramah tersebut. Itulah salah satu karakter baik yang dimiliki sekolah ini.

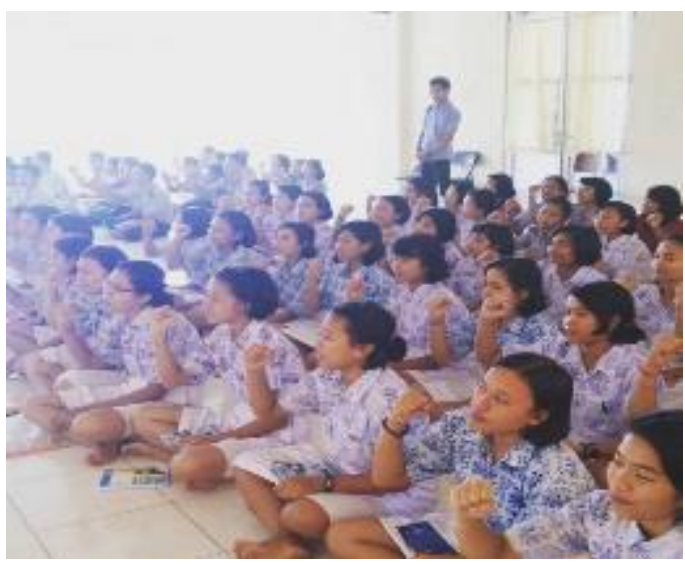

Gambar 1. Siswa SMK Bali Mandara (Sumber : Dokumentasi Pribadi)

Kemudian saat melakukan wawancara dan sosialisasi ke sekolah, Bapak
Kepala Sekolah menyatakan bahwa $70 \%$ target lulusan harus bekerja. Hal ini luar biasa sekali karena itu memang seharusnya target dari SMK manapun baik negeri maupun swasta. Keunggulan itulah yang sebenarnya dicari oleh masyarakat saat ini, terutama di tengah pandemi. Bahkan suatu saat penulis pernah menghubungi guru wali untuk merekomendasikan siswanya untuk penulis ajak bekerja dan ternyata semua alumni sudah dinyatakan sudah bekerja. Luar biasa sekali potensi yang dimiliki oleh sekolah ini.

(ㅇ. $1=$

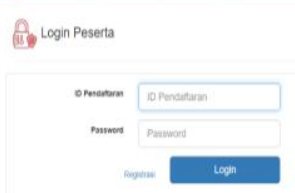

Gambar 2. Halaman Simaju yang diakses untuk gambarTest di SMKN Bali Mandara

Motivasi sekolah ini baik guru, siswa, dan kepala sekolah sangat luar biasa untuk membuka diri bekerja sama dengan Undiksha untuk mengembangkan sekolah ke arah yang semakin baik, membentuk karakter, dan menghasilkan lulusan yang unggul sesuai dengan bidangnya masingmasing. Sampai saat ini SMKN Bali Mandara memiliki tiga prodi keahlian kompetensi unggulan yaitu TKJ, TKRO, dan TGB/DPIB. Sehingga sekolah memiliki prospek yang sangat menjanjikan melalui kerjasama dengan 
mitra baik di perusahaan level Multinasional, Nasional, dan usaha lokal dan mikro. Kemndikbud tahun ini melakukan tahap kedua pelaksanaan revitalisasi SMK untuk mendorong kerjasama sekolah dengan Industri Dunia Usaha \& Dunia Kerja (InDuKa). SMK terus diarahkan untuk membuat terobosan dalam pembelajaran berbasis link and match (Kemendikbud, 2018).

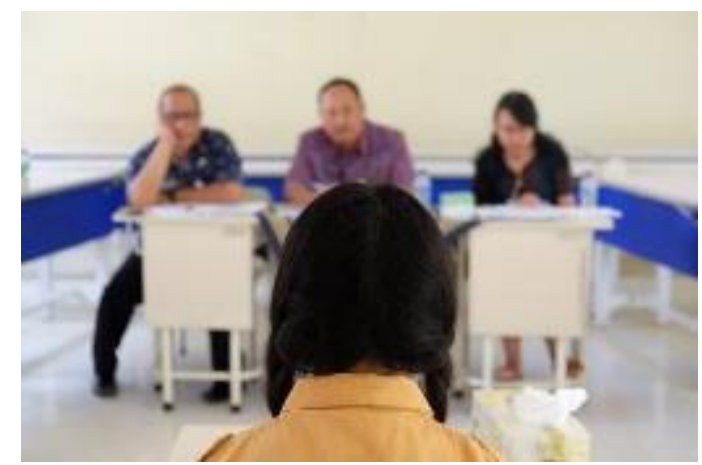

Gambar 3. Siswa Mengikuti Tes

Wawancara di SMKN Bali Mandara

Dengan tiga program keahlian ini, prospek sekolah kedepannya cukup baik karena program keahlian yang ditawarkan adalah keahlian yang termasuk dalam propek kerja yang menjandikan misalkan pada dunia industri kreatif seperti saat ini membutuhkan tenaga desain, animasi dan $\mathrm{Tl}$ yang handal, hal ini dapat menjadi peluang bagi prodi TKJ dan DGIB untuk terus berinovasi dan mengikuti kebutuhan pasar. Kemudian masyarakat Indonesia terkenal paling konsumtif untuk urusan motor baik dalam membeli baru ataupun modifikasi dan tidak segan untuk mengeluarkan dana besar untuk hal ini. Tentu akan memberikan peluang yang sangat bagus untuk prodi TKRO (Ranesia, 2018), (Pubowati, 2019).

Adapun permasalahan yang dihadapi sekolah saat ini sesuai dengan hasil diskusi dengan guru saat pelatihan sebelumnya adalah pada masalah konseling. Beberapa siswa sudah untuk diarahkan ke minat yang sesuai, memberikan motivasi ke siswa, mengelola emosi yang baik, serta mengarahkan karir siswa. Melalui diskusi yang menghadirkan Narasumber Dr. Kadek Suranata, M.Pd.,Kons banyak hal yang dibahas terkait konseling saat itu tentang tes peminatan jurusan dengan software. Berdasarkan hasil survey dari angket yang sudah diisi oleh peserta pelatihan, hampir semua responden mengatakan puas dan ingin mengikuti pelatihan $90 \%$ mengatakan sangat puas dan menginginkan pelatihan serupa, dan beberapa meginginkan produk yaitu aplikasi dikembangkan ke dalam bentuk aplikasi mobile yang dapat diakses melalui smartphone. Dengan mengembangkan aplikasi berbasis mobile, memudahkan siswa untuk melakukan instalasi dan memudahkan guru untuk melakukan konseling berbasis cyber counseling.

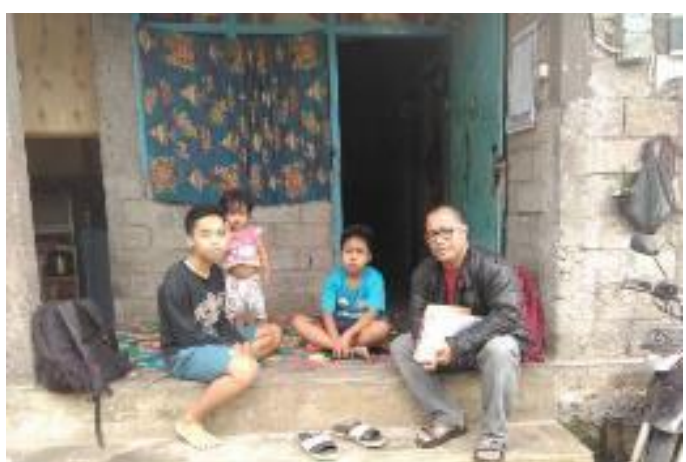

Gambar 4. Kunjungan Rumah (Home Visit) SMKN Bali Mandara 


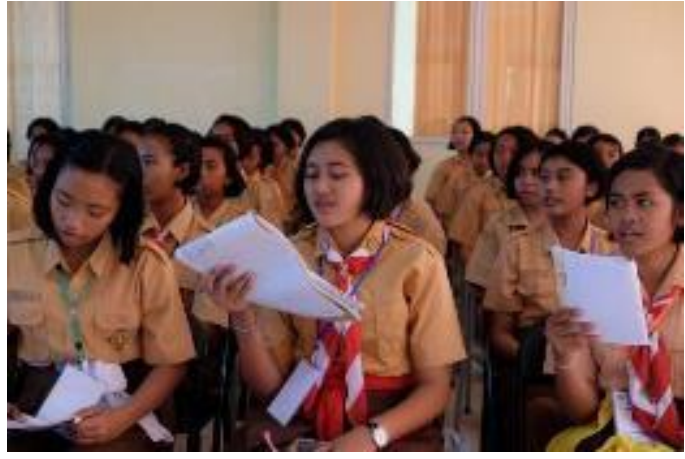

Gambar 5. Karantina (Bootcamp) di SMKN Bali Mandara

Konseling adalah hal yang sangat krusial di sekolah untuk membentuk karakter siswa ke arah yang baik, membuat siswa nyaman dalam belajar, menguasai kompetensi sesuai yang diharapkan dan mengarahkan siswa ke karir yang sesuai. Seseorang dikatakan kompeten di suatu bidang apabila memenuhi telah memenuhi aspek pengetahuan, keterampilan, dan sikap. Pengetahuan, keterampilan, dan sikap (PKS) sangat dipengaruhi oleh sistem pembelajaran dan lingkungan belajar. Hal yang paling penting adalah mengarahkan siswa ke lokasi magang yang sesuai dengan kompetensinya karena akan sangat besar pengaruhnya dengan karir mereka di masa depan. Pada masa pandemi seperti ini, konseling berbasis daring dapat dilakukan melalui aplikasi TIPS yang berbasis web dan mobile. Sehingga guru lebih mudah untuk mengarahkan peserta magang ke lokasi yang sesuai dengan kompetensi yang dimilikinya sehingga program magang dapat berjalan maksimal dan hasil yang diharapkan adalah sesuai dengan target sekolah.
Berdasarkan pengabdian yang telah dilakukan sebelumnya, guru mengharapkan pengabdi dapat membantu dalam hal konseling khususnya untuk mengarahkan siswa ke kompetensi untuk memetakan karir siswa di dunia industri. Sehingga siswa dapat terserap bekerja ke dunia industri sebanyak mungkin sesuai dengan target sekolah. Dengan dikembangkannya aplikasi mobile, hal ini dapat membantu siswa dalam melakukan tes kompetensi yang dapat digunakan untuk melakukan seleksi dan mengarahkan siswa ke lokasi magang yang sesuai dengan hasil tes inventory personal survey (TIPS) dari aplikasi Simajuganesha.com.

Peserta pelatihan ini adalah Guru TI dan BK dan tim panitia yang terlibat dalam proses seleksi magang di SMKN Bali Mandara. Melalui proses observasi ke sekolah dan wawancara dan diskusi yang mendalam oleh tim P2M dengan mitra, diperoleh informasi bahwa kedua mitra ingin mendapatkan pelatihan Cyber Counseling untuk membantu guru di sekolah dalam melakukan bimbingan konseling. memaksimalkan peran guru sebagai pendidik dan pendamping di sekolah maupun dari luar sekolah untuk membantu mengarahkan siswa memiliki keterampilan sesuai dengan yang diharapkan saat lulus, kemudian penentuan arah karir dari siswa sehingga tidak bingung mau bekerja dimana dengan kemampuan apa yang harus dimiliki.

Program pengabdian tentang pelatihan Cyber Counseling dilakukan sesuai dengan permintaan sekolah baik daring atau semidaring, mengingat kondisi yang belum stabil karena 
COVID 19. Peserta pelatihan yang awalnya adalah seluruh panitia yang terlibat dalam tim magang, sekarang di prioritaskan pada tim TI dan Guru BK yang berjumlah 15 Orang. Sehingga proses pelatihan aplikasi dapat dilakukan sementara dengan daring dan apabila sudah normal baru dilaksanakan pendampingan secara langsung.

Tingkat kemampuan peserta sudah terbiasa menggunakan perangkat $\mathrm{TI}$ karena merupakan tim $\mathrm{TI}$ dan kemampuan guru di SMK Bali Mandara sesuai dengan observasi sudah terbiasa menggunakan TI. Sehingga proses pengabdian secara daring di tengah pandemi seperti ini memungkinkan untuk dilaksanakan dengan aman sesuai dengan aturan yang berlaku. Keberadaan Lab Komputer dan Konseling juga sangat menujang untuk implementasi proses seleksi di kemudian hari untuk memudahkan proses peminatan dan magang di sekolah.

\section{METODE}

Dalam proses untuk mencapai hasil yang diharapkan dari PkM ini, memerlukan suatu metode. Berdasarkan analisis situasi dan wawancara yang dilakukan, metode PkM yang digunakan adalah seperti Gambar 6. Gambar 6 memiliki lima tahapan yang dilakukan dalam melaksanakan P2M ini, yang dapat dijelaskan seperti berikut.

1. Dalam PkM akan dilaksanakan beberapa kegiatan yang merupakan solusi untuk menyelesaikan permasalahan yang dihadapi mitra.
Terdapat beberapa solusi yang ditawarkan kepada mitra seperti yang sudah dijelaskan sebelumnya.

2. Sosialsisasi dan Diseminasi : sebelum melaksanakan PkM, perlu melakukan sosialisasi terlebih dahulu ke mitra untuk memastikan tujuan dilaksanakan kegiatan PkM, program yang dibawakan dan waktu pelaksanaan kegiatan apabila situasi sudah normal dan bebas dari COVID 19.

3. Pelatihan : Proses pelatihan dilakukan langsung ke sekolahsekolah mitra meliputi pelatihan tes kompetensi berbasis Mobile, pelatihan untuk bimbingan dan konseling untuk siswa yang magang, dan pembuatan pohon karir.

4. Pendampingan : Proses pendampingan dilakukan dengan datang langsung ke mitra, menanyakan permasalahan yang dihadapi berdasarkan pada pengalaman pelatihan yang telah dilaksanakan seelumnya.

5. Focus Group Discussion (FGD) : melakukan diskusi dan pembicaraan terkait dengan permasalahan yang sedang dihadapi mitra untuk mengantisipasi hal-hal yang tidak diinginkan selama program berlangsung secara daring. Selain itu juga dilakukan evaluasi terhadap kemampuan yang dimiliki oleh mitra setelah proses pelatihan dan pendampingan 
Jurnal Widya Laksana, Vol.10, No.2, Agustus 2021

Seluruh peserta yang akan mengikuti pelatihan serta mempersiapkan diri dengan perangkat komputer atau laptop untuk melaksanakan kegiatan PkM. Terdapat solusi dan metode yang diterapkan untuk permasahalan yang sedang dihadapi mitra seperti Tabel 2. Melalui FGD dan pendampingan merupakan sebuah cara untuk melakukan evaluasi keberlanjutan terhadap program PkM di lapangan.

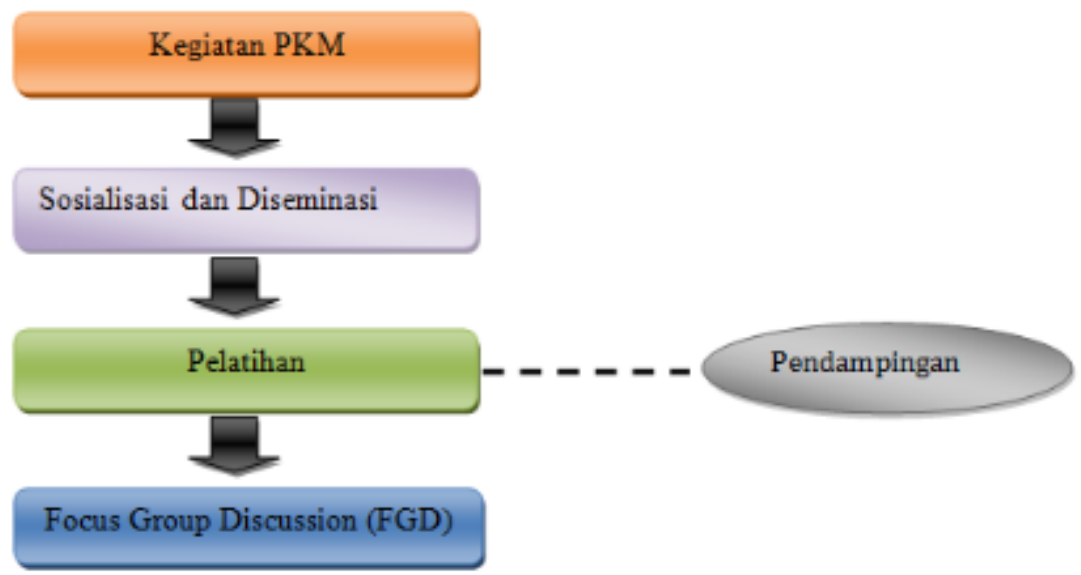

Gambar 6. Metode PkM

Tabel 2. Hubungan antara permasalahan, solusi, dan metode dalam P2M

\begin{tabular}{|c|c|c|c|c|}
\hline No & Masalah & Solusi & Metode & Luaran \\
\hline 1 & $\begin{array}{l}\text { Pemilihan } \\
\text { Lokasi } \\
\text { Magang } \\
\text { Sesuai } \\
\text { Kompetensi } \\
\text { Siswa }\end{array}$ & 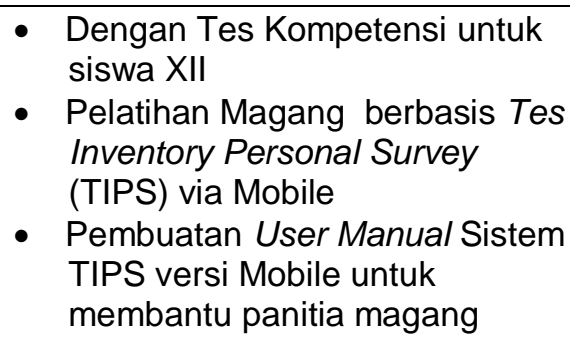 & $\begin{array}{l}\text { Sosialsisasi } \\
\text { dan } \\
\text { Diseminasi, } \\
\text { Pelatihan, } \\
\text { Pendampingan, } \\
\text { FGD }\end{array}$ & $\begin{array}{ll}\text { - } & \text { User } \\
& \text { manual } \\
\text { - } & \text { Hasil tes } \\
& \text { kompetensi }\end{array}$ \\
\hline 3 & $\begin{array}{l}\text { Perencanaan } \\
\text { Karir }\end{array}$ & $\begin{array}{l}\text { - Sosialisasi pemetaan Karir dan } \\
\text { peluang kerja } \\
\text { - Pengembangan Pohon Karir } \\
\text { sebagai landasan untuk } \\
\text { menentukan arah karir } \\
\text { - Tips memilih lokasi magang } \\
\text { yang membuat cocok untuk } \\
\text { karir }\end{array}$ & $\begin{array}{l}\text { Sosialsisasi, } \\
\text { Pelatihan, } \\
\text { Pendampingan, } \\
\text { FGD }\end{array}$ & $\begin{array}{l}\text { - Pemetaan } \\
\text { lokasi } \\
\text { magang } \\
\text { - Poster } \\
\text { Pohon } \\
\text { Karir }\end{array}$ \\
\hline
\end{tabular}




\section{KESIMPULAN DAN HASIL}

Berdasarkan hasil pengabdian yang dilakukan. Proses pelatihan dan pendampingan berjalan dengan baik dan lancar. Sebelum melakukan pengabdian, tim bersurat terlebih dahulu kepada sekolah. Adapun koordinasi dengan guru dengan mengirimkan surat pengantar terlebih dahulu kepada guru ditugaskan dilakukan melalui WhatsApp seperti pada Gambar 7.

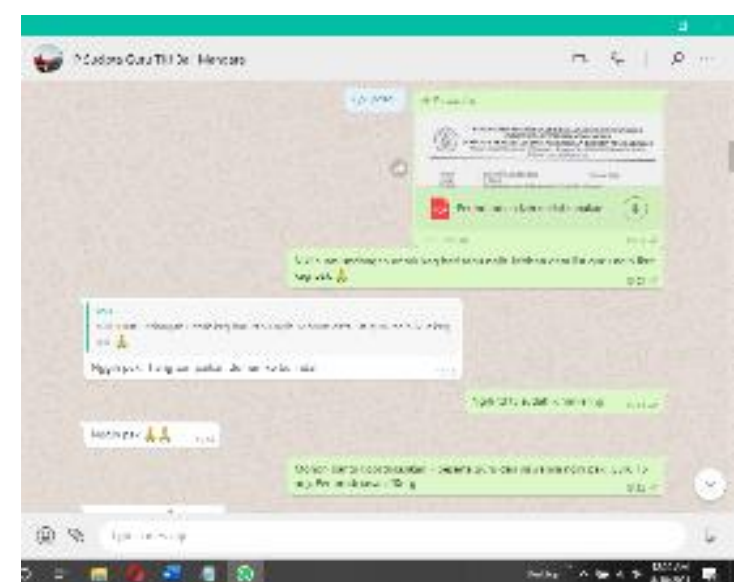

Gambar 7. Koordinasi rencana kegiatan dan pelatihan dengan pihak sekolah

Pelatihan dan pendampingan dilakukan dalam 2 tahapan. Pertama adalah dengan siswa kelas XII jurusan TKJ, kemudian yang kedua adalah pelatihan dan pendampingan dengan guru dan perwakilan kelas XII dari prodi TKJ, TGIB, dan TKR.

Pada kegiatan tahap pertama, tim berkoordinasi dengan guru yang ditugaskan untuk mengarahkan siswa menginstall aplikasi APK di smartphone, kemudian mengakses via aplikasi untuk melakukan tes kompetensi magang. Beberapa siswa sempat mengalami kendala seperti tidak dapat login, lupa password, tidak bisa melakukan ujian, nilai ujian tidak muncul sehinga perlu pedampingan dan arahan dengan memberikan buku manual penggunaan sistem untuk dapat melakukan tes secara mandiri. Sebanyak 26 Siswa mengikuti tes dengan hasil tes kompetensi seperti pada Gambar 8.

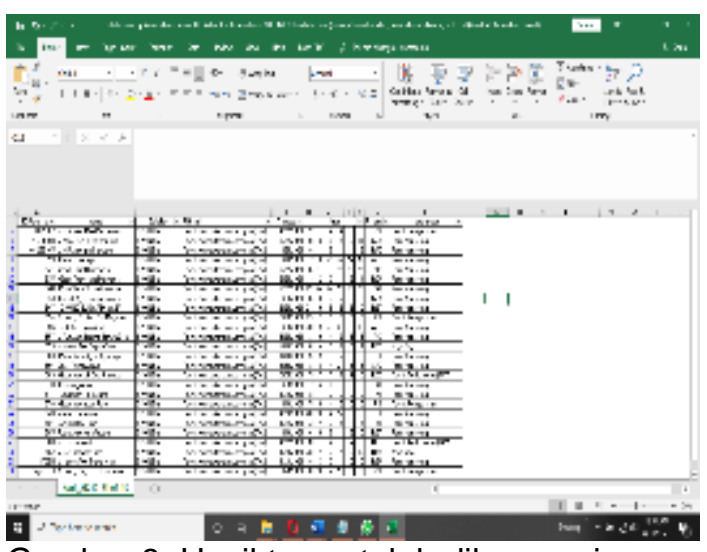

Gambar 8. Hasil tes setelah dikonversi dalam bentuk Excel

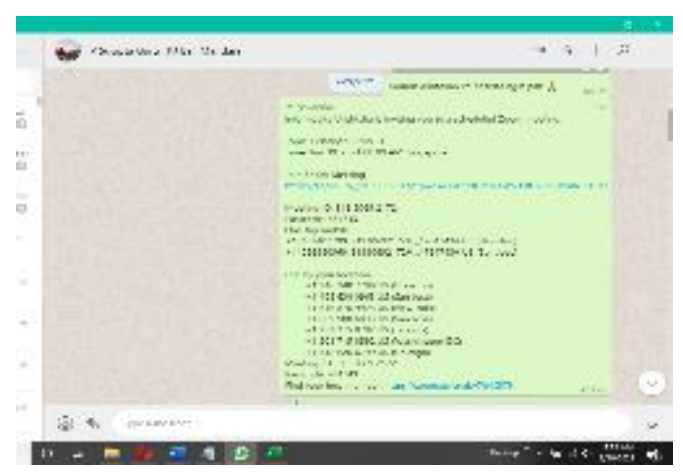

Gambar 9. Link Zoom untuk Peserta Pelatihan

Setelah melakukan pelatiahan dan pendampingan tahap 1, maka dilantukan dengan melakukan kegiatan tahap 2. Setelah melakukan koordinasi 
dan menyepakati kapan jadwal kegiatan, selanjutnya tim mengirimkan link zoom dan absensi kepada peserta pelatihan seperti pada Gambar 9 . Proses pelatihan berjalan dengan baik dengan 2 Narasumber yaitu :

1. Agus Aan Jiwa Permana, S.Kom. M.Cs dengan topik cara menggunakan aplikasi untuk tes kompetensi magang.

2. Dr. Kadek Suranata, M.Pd., Kons. dengan membawakan topik pentingnya mengetahui kompetensi magang untuk mendapatkan tempat PKL yang sesuai dan arah karir.

Adapun beberapa dokumentasi hasil pelatihan dapat dilihat pada foto Gambar 10-15. Pelatihan dan pendampingan tahap 2 ini diikuti oleh 65 Orang peserta dari Guru dan Siswa kelas XII. Dengan 15 Orang Guru dan 50 Orang Siswa.

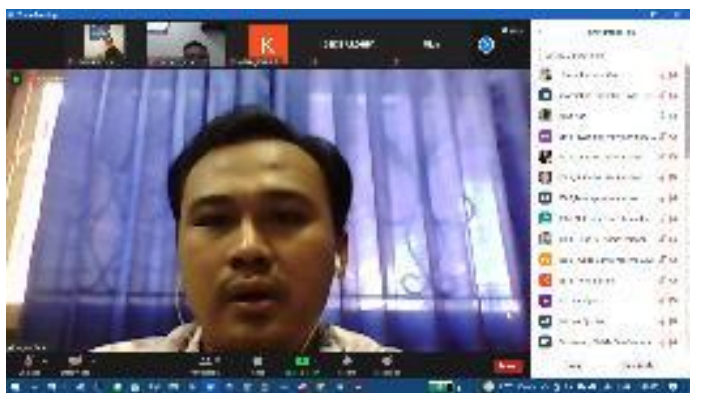

Gambar 10. Narasumber 1

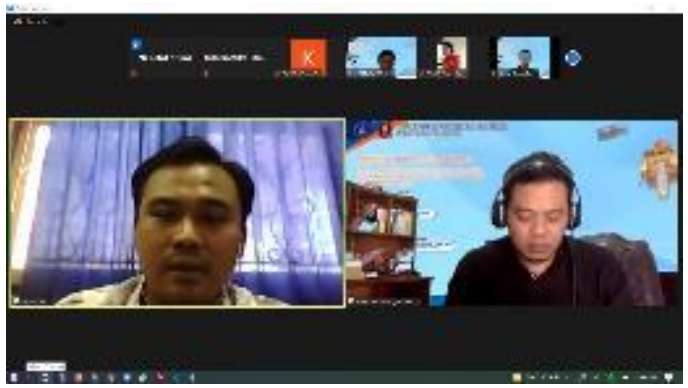

Gambar 11. Narasumber $1 \& 2$

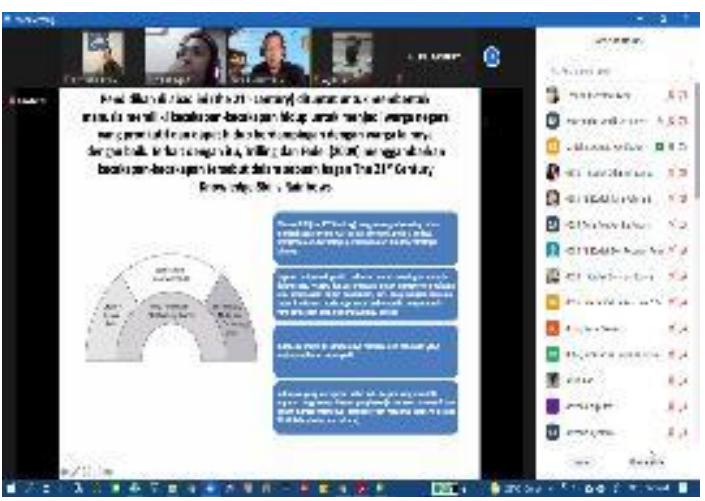

Gambar 12. Materi Narasumber 2

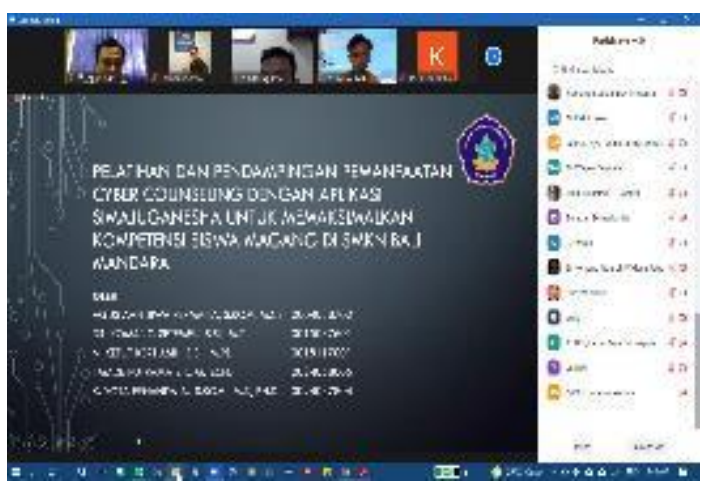

Gambar 13. Slide Pembukaan

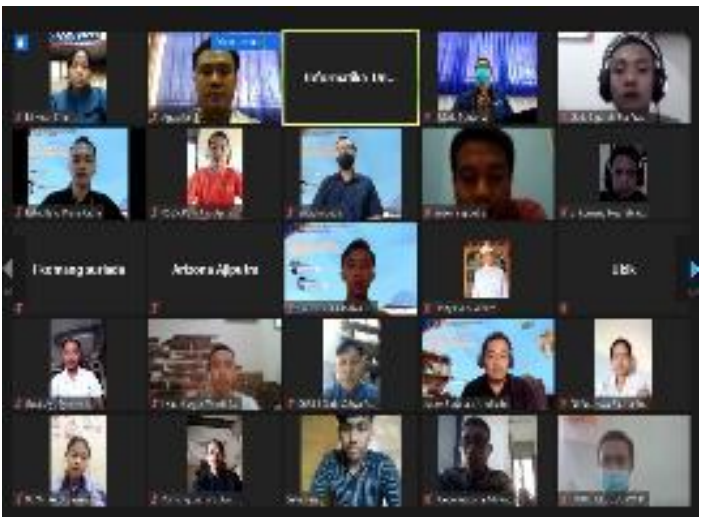

Gambar 14. Peserta Pelatihan 


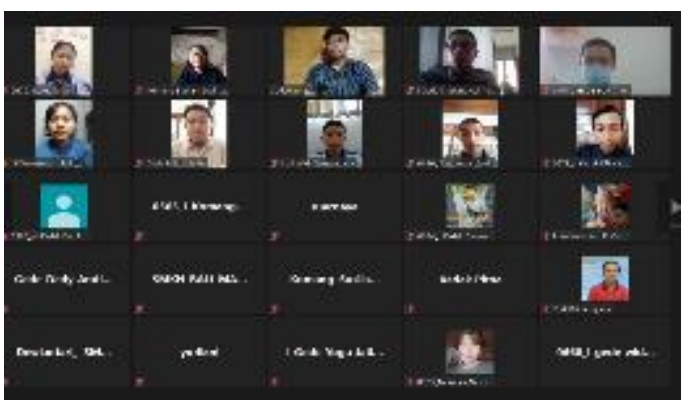

Gambar 15. Peserta Pelatihan

Adapun hasil dari pelatihan ini adalah peserta sudah paham terhadap fungsi aplikasi baik dalam website (Gambar 16) maupun aplikasi mobile (Gambar 17).

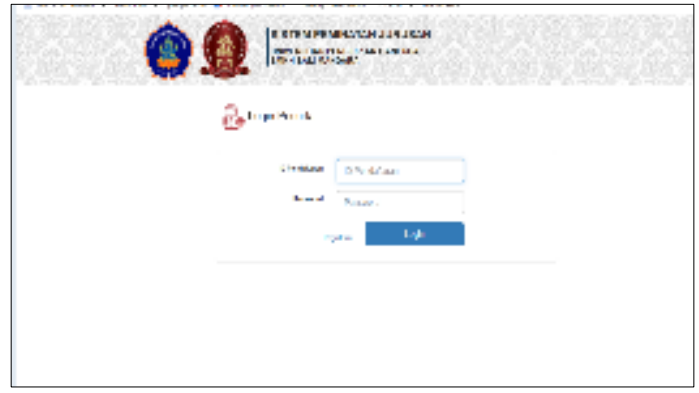

Gambar 16. Aplikasi Simaju Ganesha https://simajuganesha.com/log/index.php? module=login

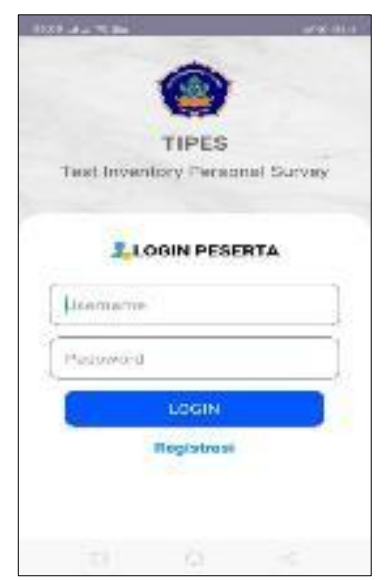

Gambar 17. Aplikasi Mobile
Adapun beberapa pesan dan kesan saat pelatihan dapat disampaikan seperti berikut :

- Pesan saya tidak ada, kesan saya yaitu saya dapat mengetahui skill saya.

- Informasi sangat bermanfaat untuk meningkatkan kualitas pelayanan sekolah kepada siswa

- Kesan saya,saya dapat menemukan cara untuk menemukan bakat dan minat saya dengan mengikuti bimbingan ini

- semoga dengan mengikuti zoom meeting pada hari ini saya bisa lebih memahami skill yang saya miliki dan bisa mengembangkannya sesuai dengan pengetahuan yang sudah saya dapatkan disini, terimakasih banyak.

- Saya senang bisa mengikuti pelatihan ini, karena pelatihan ini sangat bermanfaat, utamanya untuk kami siswa PKL. Saya harap kedepannya ada event seperti ini lagi.

- Penjelasan Simaju Ganesha yang sangat luar biasa

- Kesan saya mengikuti pelatihan daring ini sangat menyenangkan, mendapat pengalaman baru, serta pembekalan.

- Saya sangat berminat dengan aplikasi tersebut karena dari aplikasi tersebut kita bisa mengetahui skill atau kopetensi apa yang kita bisa

- setelah mengikuti pelatihan saya merasa tertarik untuk menerapkan kepada anak didik saya

- Pada pelatihan hari ini saya mendapat gambaran tentang kompetensi keahlian saya yang nantinya akan saya gunakan untuk 
Jurnal Widya Laksana, Vol.10, No.2, Agustus 2021

bekerja, semoga di lain kesempatan pelatihan ini bisa terlaksana secara tatap muka

- Pelatihan ini memberikan kesan yang luar biasa serta menambah pengalaman baru

- Senang dan bangga

- Sangat Menyenangkan

- Mengedukasi

Berdasarkan hasil pelatihan, maka dapat kesimpulannya adalah pelatihan dan pendampingan aplikasi untuk melakukan Cyber Counseling tes kompetensi magang berbasis mobile sudah dapat sesuai dengan tujuan yang diharapkan. Siswa dapat menggunakan tes sebelum magang, untuk mengetahui kompetensinya, kemudian Guru dapat membantu mengarahkan siswa ke lokasi magang yang sesuai dengan mitra sekolah. Aplikasi perlu dilakukan maintenance sesuai dengan kebutuhan di lapangan dan supaya menyediakan akses yang cepat dan lancar kepada pengguna. Berdasarkan masukan saat pelatihan, peserta merasa senang mengikuti pelatihan dan berharap nanti aplikasi ini bermanfaat membantu mengarahkan karir mereka di masa depan.

\section{DAFTAR PUSTAKA}

Kemendikbud, 2018, Ciptakan Terobosan Kerja Sama SMK dengan Dunia Industri, https://www.kemdikbud.go.id/main/ blog/2018/03/ciptakan-terobosankerja-sama-smk-dengan-duniaindustri

Pubowati, D, 2019, Menjanjikan: 11 Program Keahlian SMK untuk Kerja Dan Kuliah, https://akupintar.id/info-pintar//blogs/menjanjikan-11-programkeahlian-smk-untuk-kerja-dankuliah

Putri, Igha Melysa, 2013, Pengaruh Magang Terhadap Keputusan Mahasiswa Akuntansi Untuk Berkarir Di Bidang Akuntansi , Skipsi, Fakultas Ekonomika Dan Bisnis Universitas Diponegoro, SEMARANG

Ranesia, 2018, 10 Jurusan SMK Dengan Prospek Kerja Menjanjikan Masa Depan Cerah, https://www.renesia.com/10jurusan-smk-dengan-prospekkerja-menjanjikan/

Suarta, I Made. 2010. "Hubungan Sistem Pembelajaran, Lingkungan Belajar, Konsep Diri Dan Pengembangan." Jurnal Penelitian Dan Evaluasi Pendidikan, 24-41.

Susanti, A., 2019, Ayo buat sendiri pohon karir dan pohon jabatan SMP/SMA/SMK, Guru BK zaman now harus kreatif, ini dia caranya, https://wadahgurubk.com/post/doit-your-self-diy-membuat-sendiripohon-karir-dan-pohonjabatan/index.html, (diakses: 5 September 2019, 11:59) 